\title{
Fluid therapy for septic shock resuscitation: which fluid should be used?
}

\author{
Fluidoterapia para a ressuscitação no choque séptico: \\ qual tipo de fluido deve ser utilizado?
}

\author{
Thiago Domingos Corrêa ${ }^{1}$, Leonardo Lima Rocha ${ }^{1}$, Camila Menezes Souza Pessoa ${ }^{1}$, \\ Eliézer Silva ${ }^{1}$, Murillo Santucci Cesar de Assuncao ${ }^{1}$
}

\begin{abstract}
Early resuscitation of septic shock patients reduces the sepsis-related morbidity and mortality. The main goals of septic shock resuscitation include volemic expansion, maintenance of adequate tissue perfusion and oxygen delivery, guided by central venous pressure, mean arterial pressure, mixed or central venous oxygen saturation and arterial lactate levels. An aggressive fluid resuscitation, possibly in association with vasopressors, inotropes and red blood cell concentrate transfusion may be necessary to achieve those hemodynamic goals. Nonetheless, even though fluid administration is one of the most common interventions offered to critically ill patients, the most appropriate type of fluid to be used remains controversial. According to recently published clinical trials, crystalloid solutions seem to be the most appropriate type of fluids for initial resuscitation of septic shock patients. Balanced crystalloids have theoretical advantages over the classic solutions, but there is not enough evidence to indicate it as first-line treatment. Additionally, when large amounts of fluids are necessary to restore the hemodynamic stability, albumin solutions may be a safe and effective alternative. Hydroxyethyl starches solutions must be avoided in septic patients due to the increased risk of acute renal failure, increased need for renal replacement therapy and increased mortality. Our objective was to present a narrative review of the literature regarding the major types of fluids and their main drawbacks in the initial resuscitation of the septic shock patients.
\end{abstract}

Keywords: Schock, septic; Ressuscitation/methods; Fluid therapy; Colloids; Hydroxyethil starch derivatives; Albumins

\section{RESUMO}

A ressuscitação precoce de pacientes com choque séptico tem o potencial de reduzir sua morbidade e mortalidade. Os objetivos principais da ressuscitação no choque séptico incluem expansão volêmica, manutenção da perfusão tecidual e da oferta de oxigênio para os tecidos, guiados pela pressão venosa central, pressão arterial média, saturação venosa mista ou central de oxigênio e lactato arterial. Uma ressuscitação agressiva com fluidos, possivelmente em associação com vasopressores, inotrópicos e transfusão de concentrado de hemácias, pode ser necessária para atingir estes objetivos hemodinâmicos. Todavia, embora a administração de fluidos seja uma das intervenções mais comumente realizada em pacientes graves, o tipo de fluido mais apropriado para ser utilizado permanece controverso e incerto. De acordo com os estudos clínicos mais recentes, os cristaloides são os fluidos de escolha para serem utilizados na ressuscitação inicial de pacientes com choque séptico. As soluções cristaloides balanceadas possuem vantagens teóricas em relação as não balanceadas, porém ainda não há evidências suficientes para indicá-las como tratamento de primeira escolha. Além disso, albumina humana parece ser uma alternativa segura e efetiva quando grandes quantidades de fluidos são necessárias para o restabelecimento da estabilidade hemodinâmica. 0 uso de soluções de hidroxetilamido deve ser evitado em pacientes sépticos, devido ao maior risco de desenvolvimento de insuficiência renal aguda, necessidade de terapia de substituição renal e aumento de mortalidade. 0 objetivo deste estudo foi apresentar uma revisão narrativa da literatura sobre os principais tipos de fluidos e os problemas mais importantes na ressuscitação inicial de pacientes com choque séptico.

Descritores: Choque séptico; Ressuscitação/métodos; Hidratação; Coloides; Derivados de hidroxietil amido; Albuminas

\section{INTRODUCTION}

Septic shock is defined as a systemic inflammatory response syndrome, triggered by an infection associated with refractory hypotension, despite a fluid load of $30 \mathrm{~mL} / \mathrm{kg}$ of body weight. ${ }^{(1)}$ Septic shock remains a major cause of morbidity and mortality among critically ill

\footnotetext{
Hospital Israelita Albert Einstein, São Paulo, SP, Brazil.

Corresponding author: Murillo Santucci Cesar de Assuncao - Avenida Albert Einstein, 627/701 - Morumbi - Zip code: $05652-900$ - São Paulo, SP, Brazil - Phone: (55 11) 2151-1521 E-mail: murilloassuncao@gmail.com

Received on: Sep 30, 2014 - Accepted on: Mar 14, 2015

DOI: 10.1590/\$1679-45082015RW3273
} 
patients, with a mortality rate between 20 to $45 \%$. $^{(2-5)}$ Even though most deaths in septic shock have been attributed to progression to multiple organ failure syndrome, the puzzle concerning sepsis-related organ dysfunction and failure remains unsolved.(6) Systemic inflammation, microvascular abnormalities, tissue hypoperfusion, mitochondrial dysfunction and the therapeutic interventions made on septic patients may contribute to progression towards organ failure and death. ${ }^{(6)}$

The landmark of septic shock is systemic vasodilation, with different levels of hypovolemia. ${ }^{(7)}$ Fluid administration is the first-line intervention to restore the systemic hemodynamics and increase oxygen delivery to match oxygen demand in septic patients. ${ }^{(7)}$ According to the Surviving Sepsis Campaign Guidelines, septic patients presenting tissue hypoperfusion, hypotension or signs of hypovolemia and admitted to the emergency department must receive an initial fluid load with $30 \mathrm{~mL} / \mathrm{kg}$ of body weight of crystalloids. ${ }^{(1)}$ Patients with sustained hypotension (i.e., mean arterial blood pressure - MAP $<65 \mathrm{mmHg}$ ) or those with initial arterial lactate concentration $>4.0 \mathrm{mmol} / \mathrm{L}$, must be resuscitated following the goal-directed therapy protocol, i.e., resuscitation guided by central venous pressure (CVP), MAP, and central venous oxygen saturation $\left(\mathrm{ScrO}_{2}\right)$ or mixed venous oxygen saturation $\left(\mathrm{SvO}_{2}\right){ }^{(1)}$ The goals to be achieved during the initial 6 hour resuscitation include: a CVP between 8 and $12 \mathrm{mmHg}$, in spontaneous breathing, or between 12 and $15 \mathrm{mmHg}$, in patients under mechanical ventilation; a MAP > 65mmHg; and $\mathrm{ScvO}_{2}$ or $\mathrm{SvO}_{2}>70 \%$ and $65 \%$, respectively. Alternatively, a lactate clearance $>10 \%$ may be target during this first 6 hours, in place of the $\mathrm{ScvO}_{2}$, in patients with no central venous catheter. ${ }^{\left({ }^{(2)}\right.}$ Fluids, vasopressors, inotropes and red blood cells transfusion are the therapeutic interventions available at the bedside for critical care and emergency care physicians to achieve those hemodynamic goals. It is important to emphasize that many patients can be fully resuscitated only by early receiving the correct type and amount of intravenous fluids.

The question concerning which fluids should be used during the initial hours of septic patients has been a matter of debate for decades and up to now, there has been no consensus over which type of fluid is the most appropriate to be used in this context. ${ }^{(9)}$ Therefore, our objective was to present a narrative review of the literature regarding the major types of fluids and their main drawbacks for in the initial resuscitation of the septic shock patients.

\section{WHY FLUIDS ARE GIVEN?}

The reason to offer fluids to septic shock patients may be justified based on vascular bed changes. Inflammatory mediators act on endothelial cells promoting vasodilation, which results in a relative hypovolemia, i.e., loss in continent and content ratio. ${ }^{(10)}$ Therefore, an adequate fluid replacement is crucial to maintain the perfusion pressure and, most importantly, blood flow to the tissues. ${ }^{(11)}$ Tissue perfusion, systemic blood flow and oxygenation can be achieved by restoring the intravascular compartment through fluid administration. ${ }^{(12)}$

Fluids should be administered based on two assumptions: in the presence of impaired tissue perfusion (stagnant hypoxia) requiring blood flow augmentation and in the presence of fluid responsiveness, that is, when fluid administration will boost cardiac output. ${ }^{(13)}$ Both hypovolemia and fluid overload can be deleterious for critically ill patients. Therefore, whenever feasible it is advisable to address fluid responsiveness before prescribing fluids as well as to avoid fluids infusion in the patients to whom those assumptions do not apply. Inotropes should be considered to improve tissue oxygenation in patients requiring an increased blood flow but who are no longer responsive to fluid administration. ${ }^{(1)}$

Early recognition and prompt treatment are crucial to improve survival in septic shock patients. ${ }^{(14)}$ Early onset of resuscitation can restore the oxygen delivery, reverse tissue hypoxia and minimize the progression to cell and mitochondrial dysfunction and the establishment of multiple organ failure syndrome secondary to systemic inflammation and tissue hypoperfusion. ${ }^{(15)}$ Alongside with fluid therapy, infection control with early adequate antibiotics administration is essential to mitigate damage secondary to the inflammatory response. ${ }^{(16)}$ Nevertheless, tissue dysoxia can develop even after adequate fluid resuscitation, depending on the intensity of systemic inflammation and the severity of disease.

\section{TYPES OF FLUIDS}

Resuscitation fluids can be divided into two broad categories: crystalloids and colloids (Tables 1 and 2). ${ }^{(9)}$ Different types of solutions can have specific capacity of volume expansion, duration of effect, impact on vascular integrity, acid-base balance, inflammatory response, changes in red blood cell rheology and hemostasis. ${ }^{(9)}$ These alterations can result in beneficial or harmful effects, depending on the characteristics of patients and fluids. In the following sections, we will discuss the main available types of fluids for septic shock resuscitation. 
Table 1. The main crystalloid solutions and their composition ${ }^{(9)}$

\begin{tabular}{|c|c|c|c|c|c|c|c|c|}
\hline Solutions/characteristics & Osmolality (m0sm/L) & $\mathrm{pH}$ & Sodium (mEq/L) & Chloride (mEq/L) & Potassium (mEq/L) & Calcium (mEq/L) & Magnesium (mEq/L) & Buffers $(\mathrm{mEq} / \mathrm{L})$ \\
\hline Plasma & 290 & 7.4 & 140 & 103 & 4 & 4 & 2 & Bicarbonate (24) \\
\hline Normal saline $(0.9 \% \mathrm{NaCl})$ & 308 & 5.7 & 154 & 154 & 0 & 0 & 0 & 0 \\
\hline Ringer's injection & 309 & 5.8 & 147 & 156 & 4 & 4 & 0 & 0 \\
\hline Ringer lactate & 273 & 6.5 & 130 & 109 & 4 & 3 & 0 & Lactate (28) \\
\hline Ringer acetate & 275 & 6.7 & 131 & 109 & 4 & 3 & 0 & Acetate (28) \\
\hline Plasma-Lyte & 295 & 7.4 & 140 & 98 & 5 & 0 & 3 & $\begin{array}{c}\text { Acetate (28) } \\
\text { Gluconate (23) }\end{array}$ \\
\hline
\end{tabular}

Table 2. The main colloidal solutions and their composition ${ }^{(9)}$

\begin{tabular}{|c|c|c|c|c|c|c|c|}
\hline \multirow{2}{*}{$\begin{array}{l}\text { Solutions/characteristics } \\
\text { Solution concentration }\end{array}$} & \multicolumn{2}{|c|}{ Albumin } & \multicolumn{2}{|c|}{ Hydroxyethyl starch } & \multicolumn{2}{|c|}{ Dextran } & \multirow[t]{2}{*}{ Gelatins } \\
\hline & $4 \%, 5 \%$ & $20 \%, 25 \%$ & $\begin{array}{l}6 \%, 10 \% \\
\text { pentastarch }\end{array}$ & $\begin{array}{c}6 \% \\
\text { hetastarch }\end{array}$ & $10 \%$ Dextran 40 & $\begin{array}{l}\text { 3\% Dextran } 60 \\
6 \% \text { Dextran } 70\end{array}$ & \\
\hline Molecular weight & 69 & & $100-450$ & & $40-70$ & & $30-35$ \\
\hline Osmolality (mOsm/L) & 300 & 1.500 & $300-326$ & & $280-324$ & & $300-350$ \\
\hline Oncotic pressure $(\mathrm{mmHg})$ & $19-30$ & $74-120$ & $23-82$ & & $20-60$ & & $25-42$ \\
\hline Plasmatic expansion (\%) & $70-100$ & $200-300$ & $100-160$ & & $100-200$ & $80-140$ & $70-100$ \\
\hline Duration of plasmatic expansion (h) & $\leq 24$ & & $\leq 12$ & $\leq 4-36$ & $\leq 4-6$ & $\leq 8-24$ & $\leq 4-6$ \\
\hline Plasma half-life (h) & $16-24$ & & $2-12$ & & 2 & $\sim 24$ & $\sim 2-9$ \\
\hline Possible adverse effects & \multicolumn{2}{|c|}{$\begin{array}{l}\text { High cost, risk of infection and } \\
\text { anaphylactic reactions }\end{array}$} & \multicolumn{2}{|c|}{$\begin{array}{l}\text { Impairment coagulation, pruritus, } \\
\text { acute kidney failure, and } \\
\text { anaphylactic reactions }\end{array}$} & \multicolumn{2}{|c|}{$\begin{array}{l}\text { Changes in blood viscosity, coagulopathy, renal } \\
\text { dysfunction, and anaphylactic reactions }\end{array}$} & $\begin{array}{c}\text { Hypercalcemia and } \\
\text { anaphylactic reactions }\end{array}$ \\
\hline
\end{tabular}

\section{CRYSTALLOIDS}

Crystalloid solutions have been recommended as a first choice to resuscitate septic shock patients and nowadays they are the most used type of fluids in the Unites States. (1,9) "Crystalloid" is the most popular term used to refer to solutions containing water, inorganic ions and small organic molecules. Crystalloids are composed of glucose or sodium chloride solutions, and can be hypotonic, isotonic or hypertonic. Some of them can have other components, such as potassium or calcium, and can use some buffers as lactate or acetate to become plasma-like. ${ }^{(9)}$

Normal saline $(0.9 \% \mathrm{NaCl})$ is considered an isotonic solution, with osmolality closer to the plasma osmolality $(287 \mathrm{mOsm} / \mathrm{kg})$ and it contains a sodium concentration of $154 \mathrm{mEq} / \mathrm{L}$ and a chloride concentration of $154 \mathrm{mEq} / \mathrm{L}$, which is 1.5 -fold higher than the physiologic serum concentration of chloride. This is the reason for normal saline being considered a non-balanced solution..$^{(9)}$ Because normal saline has a higher chloride concentration, large volume infusions can promote hyperchloremic acidosis, also known as dilution hyperchloremic acidosis, which can be explained by the strong ion difference (SID) approach. ${ }^{(17)}$

SID is defined as the difference between cations and anions dissociated in plasma. ${ }^{(17)}$ In a 70-kg healthy man, the sodium and chloride plasma concentrations are approximately $140 \mathrm{mEq} / \mathrm{L}$ and $100 \mathrm{mEq} / \mathrm{L}$, respectively, and the total body water is around 42L. Therefore, in healthy individuals, the cation concentration exceeds that of anions, resulting in a difference of $40 \mathrm{mEq} / \mathrm{L}$ (plama $\mathrm{SID}=40 \mathrm{mEq} / \mathrm{L}$ ). Under those conditions, the total body sodium and chloride concentrations are, respectively, $5,880 \mathrm{mEq}$ and $4,200 \mathrm{mEq}$. If that individual receives $10 \mathrm{~L}$ of normal saline, it will add $1,540 \mathrm{mEq}$ in plasma sodium and $1,000 \mathrm{mEq}$ in plasma chloride, resulting in final total body sodium and chloride of $7,420 \mathrm{mEq}$ and $5,200 \mathrm{mEq}$, respectively. The total body water will be also increased from 42 to 52L. Accordingly, the SID is reduced to $32 \mathrm{mEq} / \mathrm{L}$, as sodium and chloride concentrations increases to 142.7 and to $110 \mathrm{mEq} / \mathrm{L}$, respectively. ${ }^{(18,19)}$ This occurs because normal saline contains strong cations and strong anions in the same quantity, i.e., its SID is zero. Thus, infusion of normal saline will reduce the SID of plasma and, therefore, decrease the plasma $\mathrm{pH}$. In general, acidosis is mild to moderate, base excess variation is not higher than $-10 \mathrm{mEq} / \mathrm{L}$ and rarely the $\mathrm{pH}$ reaches less than 7.30 after respiratory compensation. ${ }^{(20)}$ If normal saline infusion is interrupted, the effects are expected to be transitory and reversible within 48 hours. ${ }^{(21)}$

Besides the hyperchloremic acidosis, large amounts of normal saline infusion can compromise coagulation, 
kidney function and the immunologic response.(22) Dilutional coagulopathy occurs because all coagulation factors will be diluted by infused bulk normal saline, increasing risk of bleeding. ${ }^{(22)}$ Moreover, there is a growing body of evidence showing that normal normal saline can impair renal function. In experimental animal studies, hyperchloremia induced by normal saline showed to diminish renal blood flow and promote renal vasoconstriction. ${ }^{(23,24)}$

Balanced solutions have been proposed as an alternative to normal saline. ${ }^{(25)}$ A solution can be considered ideally balanced when it is normotonic with a SID of $24 \mathrm{mEq} / \mathrm{L}$. ${ }^{(26)}$ This can be achieved by removing $24 \mathrm{mEq} / \mathrm{L}$ of chloride from $0.9 \%$ sodium chloride solution and replacing it with bicarbonate or organic anions, which quickly disappear after infusion, such as lactate or acetate. ${ }^{(26)}$ Considering the previously described adverse events related to unbalanced solution, balanced solutions might be the ideal solution for the resuscitation of critically ill patients.

The most common used balance solutions include Ringer's injection, Ringer Lactate, Ringer Acetate and Plasma-Lyte. The Ringer Lactate was developed in the beginning of 1930s, by adding sodium lactate to Ringer solution as a buffer, reducing its chloride concentration $(109 \mathrm{mEq} / \mathrm{L})$ when compared to Ringer's injection solution (Table 1). Ringer Lactate is a mild hypotonic solution $(273 \mathrm{mOsm} / \mathrm{kg})$ and has potassium and calcium in its composition. Concerns that large amounts of Ringer Lactate infusion could increase plasma lactate levels in critically ill patients led the lactate buffer to be replaced by acetate in order to create Ringer Acetate. The composition of Ringer Lactate and acetate is almost identical with the exception of the added buffer (lactate or acetate). Plasma-Lyte is another balanced solution with osmolality of $295 \mathrm{mOsm} / \mathrm{L}$, sodium concentration of $140 \mathrm{mEq} / \mathrm{L}$ and chloride concentration of $98 \mathrm{mEq} / \mathrm{L}$. Other electrolytes and buffers making up this solution are potassium, magnesium, acetate and gluconate. In patients with impaired kidney function, this kind of solution should be avoided due to the risk of hyperkalemia (Table 1).

It was demonstrated that a chloride-restrictive strategy in critically ill patients was associated with a significant decrease in the incidence of acute kidney injury and use of renal replacement therapy.(27) Additionally, a large retrospective cohort study involving 53,448 septic patients showed that resuscitation with balanced fluids, in comparison to non-balanced solutions, decreases the risk of in-hospital death (relative risk $-\mathrm{RR}=0.86$; $95 \%$ confidence interval $-95 \%$ CI: $0.78-0.94 ; p=0.001$ ). However, no significant differences in the incidence of acute renal failure, the need of renal replacement therapy, and hospital and intensive care unit (ICU) lengths of stay were reported. ${ }^{(25)}$

Nevertheless the level of evidence to support the use of balanced solutions in clinical practice is weak. ${ }^{(28)} \mathrm{A}$ recent meta-analysis suggested that resuscitation with balanced crystalloids in comparison to unbalanced solution (normal saline $0.9 \%$ ) may be associated with lower mortality rate (odds ratio $-\mathrm{OR}=0.78 ; 95 \% \mathrm{CI}$ : $0.58-1.05){ }^{(28)}$ In this context, a large randomized trial comparing balanced and unbalanced solutions for septic shock resuscitation is still needed. ${ }^{(28)}$

\section{COLLOIDS}

Colloids are defined as homogenous non-crystalloid substances consisting of large molecules or ultramicroscopic particles of one substance dispersed through a second substance molecule with a high molecular weight. ${ }^{(29)}$ Those fluids have a relatively higher duration and capacity of intravascular expansion with lower volumes, i.e., a higher oncotic pressure when compared to crystalloids. Colloids are not able to cross the semi impermeable vascular membrane due to their high molecular weight. ${ }^{(29)}$

There are two kinds of colloids: natural and semisynthetic colloids. Human albumin in normal saline is the reference colloidal solution and it represents a natural colloid derived from human plasma. Semisynthetic colloids, by contrast, consist of derivatives of three main groups of molecules: gelatins, dextrans and starches (Table 2). To produce a colloid, these molecules are suspended in a solvent, which can be an isotonic or hypertonic normal saline, hypertonic glucose or an isotonic balanced electrolyte solution. Isotonic normal saline is the most common solvent used in colloidal solutions. Due to the scope of this review, we will focus on starch solutions and albumin.

\section{Hydroxyethyl starch}

Hydroxyethyl starch (HES), a synthetic solution made by manipulating waxy or potato amylopectin (a multibranched glucose polymer), has become some of the most frequently used colloidal plasma expanders worldwide, mainly due to their lower cost when compared to albumin. ${ }^{(30)}$ Nowadays, HES are being avoided in the treatment of critically ill patients, specifically in those with sepsis. Recent clinical data indicate that colloids do not improve patient outcomes and may be harmful depending on the setting and type of colloid. ${ }^{(31,32)}$ 
HES are identified by three numbers, e.g. $10 \%$ HES $200 / 0.5$ or $6 \%$ HES 130/0.4. They are classified according to the mean molecular weight (range: 70 to 670 kiloDalton) and the frequency of hydroxyethyl groups per glucose monomer (range: 0.4 to 0.7$){ }^{(33)}$ The first number indicates the solution concentration, the second represents the mean molecular weight expressed in kiloDalton $(\mathrm{kDa})$, and the third and most significant one is the molar substitution (MS). ${ }^{(33)}$

HES have a varying number of hydroxyethyl residues attached to the anhydrous glucose particles within the polymer. This substitution increases the solubility of starch in water and, to a varying degree, inhibits the rate of degradation of the starch polymer by amylases. ${ }^{(33)}$ Those parameters are highly relevant to the pharmacokinetics of HES. The half-life of a starch solution depends on its molecular weight, degree of substitution, and the proportion of hydroxyethyl groups in the $\mathrm{C} 2$ carbon when compared with the C6 carbon of the glucose monomer. ${ }^{(34)}$ Hydroxyethyl groups at the position of the $\mathrm{C} 2$ atom inhibit the access of alpha-amylase to the substrate more effectively than hydroxyethyl groups at the C6 position. Hence, HES produced with high $\mathrm{C} 2 / \mathrm{C} 6$ ratios are expected to be more slowly degraded. ${ }^{(34)}$ In general, HES is used for restrictive fluid strategy due to a high plasma expansion capacity with lower volume administration.

A prospective multicenter clinical trial was performed to address the frequency of acute renal failure in severe sepsis and septic shock patients resuscitated with $6 \%$ HES $(200 \mathrm{kDa}, 0.60 ; 0.66$ substitution) or $3 \%$ fluid-modified gelatin. ${ }^{(35)}$ The frequencies of acute renal failure, oliguria and the peak serum creatinine concentration were significantly higher in the HES group in comparison to the gelatin group. ${ }^{(35)}$ In this study, HES resuscitation was found to be an independent risk factor for acute renal failure $(\mathrm{OR}=2.57$; $95 \% \mathrm{CI}$ : $1.13-5.83 ; \mathrm{p}=0.026)$ in severe sepsis or septic shock patients. ${ }^{(35)}$ Other studies evaluated starches with a high or intermediate molecular weight (200 or $450 \mathrm{kDa})$ and a higher degree of molar substitution (0.5 to 0.7 ) and showed a higher incidence of renal failure or bleeding complications. $^{(36)}$

It was advocated that the third generation HES, with a lower molecular weight and lower degree of molar substitution, would have a safer profile and, therefore, would be associated to a lower incidence of adverse events (mainly bleeding complications and acute kidney injury). Hence, they could be used to treat critically ill patients. Nonetheless, this hypothesis was not confirmed in the most recent clinical trials. ${ }^{(37-39)}$ In those studies, resuscitation with a third generation of
HES was associated with an increased risk of death, acute renal failure and the need of renal replacement therapy, especially among the septic patients. ${ }^{(37-39)}$ The reported results were quite similar regardless of whether potato- or maize-derived starch were compared. ${ }^{(40)}$ In sum, the most recent literature does not support the use of HES during the resuscitation of severe sepsis and septic shock patients.

\section{Albumin}

Albumin solutions are used worldwide to treat critically ill patients. A meta-analysis carried out in 1998 associated albumin usage to high mortality rate. ${ }^{(41)}$ In this context, safety of albumin use was questioned until the SAFE study (Saline versus Albumin Fluid Evaluation) was published, which showed that albumin solutions, in comparison to crystalloids, did not increase mortality. ${ }^{(42)}$

Albumin administration can be justified based on its physiological effects, primarily binding and transportation of various substances (such as drugs and hormones) in the blood; antioxidant properties, nitric oxide modulation; and buffer capacity, which may be of particular relevance in critically ill patients, and not only to regulate osmotic pressure. ${ }^{(43)}$ Also, low serum albumin levels, a common finding in critically ill patients, were associated to worse outcomes. ${ }^{(44)}$ On the other hand, there are some limitations for a broader use of albumin solutions: their high cost, potential risk of microorganisms transmission and allergic effects when compared to crystalloids. ${ }^{(44)}$ So far, no randomized clinical trial has showed a real benefit of albumin administration. Actually, it could be noticed that some subpopulations, such as those with traumatic brain injury, can have an increased risk of death when receiving albumin solutions. ${ }^{(45)}$

A subgroup analysis among septic shock patients enrolled in the SAFE study showed a trend on mortality reduction in favor to albumin in comparison to normal saline (adjusted OR=0.71; 95\%CI: 0.52-0.97; $\mathrm{p}=0.03) .{ }^{(46)}$ More recently, the ALBIOS study (Volume Replacement With Albumin in Severe Sepsis) randomized 1,818 severe sepsis and septic shock patients to receive either $300 \mathrm{~mL}$ of $20 \%$ albumin plus crystalloid or to receive crystalloid alone from randomization until day 28 , or ICU discharge, aiming to maintain serum albumin $\geq 30 \mathrm{~g} / \mathrm{L}$. ${ }^{(47)}$ Although more patients reached the target MAP within 6 hours in the albumin group when compared to crystalloids group, neither the 28-day mortality nor the 90-day mortality rate $(\mathrm{RR}=0.94 ; 95 \% \mathrm{CI}: 0.85-1.05 ; \mathrm{p}=0.29)$ differed between the groups. ${ }^{(47)}$ 
It can be concluded that a clinical trial comparing a $4 \%$ albumin solution with crystalloids to resuscitate septic shock patients is required. For instance, albumin solution is the only colloidal solution endorsed by the Surviving Sepsis Campaign guidelines for septic patients who are not responding to crystalloid infusion. ${ }^{(1)}$

\section{CONCLUSION}

There is no consensus over which type of fluid should be used as first-line therapy to resuscitate septic shock patients. The body of evidence shows that crystalloids solutions, whether balanced or not, are the most advisable choice. Hypo-oncotic albumin solutions can be used as an alternative for those who need large amounts of fluids during the initial resuscitation phase. The hydroxyethyl starches should not be prescribed to this population due to possible deleterious effects. Further evidence on the use of albumin and balanced solutions is required.

\section{ACKNOWLEDGEMENTS}

We thank Helena Spalic for proofreading this manuscript.

\section{REFERENCES}

1. Dellinger RP, Levy MM, Rhodes A, Annane D, Gerlach H, Opal SM, Sevransky JE, Sprung CL, Douglas IS, Jaeschke R, Osborn TM, Nunnally ME, Townsend SR, Reinhart K, Kleinpell RM, Angus DC, Deutschman CS, Machado FR, Rubenfeld GD, Webb S, Beale RJ, Vincent JL, Moreno R; Surviving Sepsis Campaign Guidelines Committee including the Pediatric Subgroup. Surviving sepsis campaign: international guidelines for management of severe sepsis and septic shock, 2012. Intensive Care Med. 2013;39(2):165-228.

2. Asfar P, Meziani F, Hamel JF, Grelon F, Megarbane B, Anguel N, Mira JP, Dequin PF, Gergaud S, Weiss N, Legay F, Le Tulzo Y, Conrad M, Robert R, Gonzalez F, Guitton C, Tamion F, Tonnelier JM, Guezennec P, Van Der Linden T, VieillardBaron A, Mariotte E, Pradel G, Lesieur O, Ricard JD, Hervé F, du Cheyron D, Guerin C, Mercat A, Teboul JL, Radermacher P; SEPSISPAM Investigators. High versus low blood-pressure target in patients with septic shock. N Engl J Med. 2014;370(17):1583-93.

3. ARISE Investigators; ANZICS Clinical Trials Group, Peake SL, Delaney A, Bailey M, Bellomo R, Cameron PA, Cooper DJ, Higgins AM, Holdgate A, Howe BD, Webb SA, Williams P. Goal-directed resuscitation for patients with early septic shock. N Engl J Med. 2014;371(16):1496-506.

4. ProCESS Investigators, Yealy DM, Kellum JA, Huang DT, Barnato AE, Weissfeld LA, Pike F, Terndrup T, Wang HE, Hou PC, LoVecchio F, Filbin MR, Shapiro NI, Angus DC. A randomized trial of protocol-based care for early septic shock. N Engl J Med. 2014;370(18):1683-93.

5. Holst LB, Haase N, Wetterslev J, Wernerman J, Guttormsen AB, Karlsson S, Johansson Pl, Aneman A, Vang ML, Winding R, Nebrich L, Nibro HL, Rasmussen BS, Lauridsen JR, Nielsen JS, Oldner A, Pettilä V, Cronhjort MB, Andersen LH, Pedersen UG, Reiter N, Wiis J, White JO, Russell L, Thornberg KJ, Hjortrup PB, Müller RG, Møller MH, Steensen M, Tjäder I, Kilsand K, OdebergWernerman S, Sjøbø B, Bundgaard H, Thyø MA, Lodahl D, Mærkedahl R, Albeck C, Illum D, Kruse M, Winkel P, Perner A; TRISS Trial Group; Scandinavian Critical Care Trials Group. Lower versus higher hemoglobin threshold for transfusion in septic shock. N Engl J Med. 2014;371(15):1381-91.
6. Hotchkiss RS, Karl IE. The pathophysiology and treatment of sepsis. N Engl J Med. 2003;348(2):138-50. Review.

7. Angus DC, van der Poll T. Severe sepsis and septic shock. N Engl J Med. 2013;369(9):840-51. Review. Erratum in: Erratum in: N Engl J Med. 2013; 369(21):2069.

8. Jones AE, Shapiro NI, Trzeciak S, Arnold RC, Claremont HA, Kline JA; Emergency Medicine Shock Research Network (EMShockNet) Investigators. Lactate clearance vs central venous oxygen saturation as goals of early sepsis therapy: a randomized clinical trial. JAMA. 2010;303(8):739-46.

9. Myburgh JA, Mythen MG. Resuscitation fluids. N Engl J Med. 2013;369(13): 1243-51. Review.

10. Marx G. Fluid therapy in sepsis with capillary leakage. Eur J Anaesthesiol. 2003;20(6):429-42. Review.

11. Ospina-Tascon G, Neves AP, Occhipinti G, Donadello K, Büchele G, Simion D, et al. Effects of fluids on microvascular perfusion in patients with severe sepsis. Intensive Care Med. 2010;36(6):949-55.

12. Rady MY, Rivers EP, Nowak RM. Resuscitation of the critically ill in the ED: responses of blood pressure, heart rate, shock index, central venous oxygen saturation, and lactate. Am J Emerg Med. 1996;14(2):218-25.

13. Cecconi M, Arulkumaran N, Kilic J, Ebm C, Rhodes A. Update on hemodynamic monitoring and management in septic patients. Minerva Anestesiol. 2014; 80(6):701-11.

14. Rivers E, Nguyen B, Havstad S, Ressler J, Muzzin A, Knoblich B, Peterson E, Tomlanovich M; Early Goal-Directed Therapy Collaborative Group. Early goaldirected therapy in the treatment of severe sepsis and septic shock. N Engl J Med. 2001;345(19):1368-77.

15. Corrêa TD, Vuda M, Blaser AR, Takala J, Djafarzadeh S, Dünser MW, et al. Effect of treatment delay on disease severity and need for resuscitation in porcine fecal peritonitis. Crit Care Med. 2012;40(10):2841-9.

16. Kumar A, Roberts D, Wood KE, Light B, Parrillo JE, Sharma S, et al. Duration of hypotension before initiation of effective antimicrobial therapy is the critical determinant of survival in human septic shock. Crit Care Med. 2006;34(6): 1589-96.

17. Seifter JL. Integration of acid-base and electrolyte disorders. N Engl J Med. 2014;371(19):1821-31. Review.

18. Kellum JA. Determinants of plasma acid-base balance. Crit Care Clin. 2005; 21(2):329-46. Review.

19. Scheingraber S, Rehm M, Sehmisch C, Finsterer U. Rapid saline infusion produces hyperchloremic acidosis in patients undergoing gynecologic surgery. Anesthesiology. 1999;90(5):1265-70.

20. Morgan TJ. The meaning of acid-base abnormalities in the intensive care unit: part III -- effects of fluid administration. Crit Care. 2005;9(2):204-11. Review.

21. Kellum JA. Saline-induced hyperchloremic metabolic acidosis. Crit Care Med. 2002;30(1):259-61.

22. Smorenberg A, Ince C, Groeneveld AJ. Dose and type of crystalloid fluid therapy in adult hospitalized patients. Perioper Med (Lond). 2013;2(1):17. Erratum in: Perioper Med (Lond). 2014;3:3.

23. Nashat FS, Tappin JW, Wilcox CS. The renal blood flow and the glomerular filtration rate of anaesthetized dogs during acute changes in plasma sodium concentration. J Physiol. 1976;256(3):731-45.

24. Wilcox CS. Regulation of renal blood flow by plasma chloride. J Clin Invest. 1983;71(3):726-35.

25. Raghunathan K, Shaw A, Nathanson B, Stürmer T, Brookhart A, Stefan MS, et al. Association between the choice of IV crystalloid and in-hospital mortality among critically ill adults with sepsis*. Crit Care Med. 2014;42(7):1585-91.

26. Morgan TJ. The ideal crystalloid - what is 'balanced'? Curr Opin Crit Care. 2013; 19(4):299-307. Review.

27. Yunos NM, Bellomo R, Hegarty C, Story D, Ho L, Bailey M. Association between a chloride-liberal vs chloride-restrictive intravenous fluid administration strategy and kidney injury in critically ill adults. JAMA. 2012;308(15):1566-72.

28. Rochwerg B, Alhazzani W, Sindi A, Heels-Ansdell D, Thabane L, FoxRobichaud A, Mbuagbaw L, Szczeklik W, Alshamsi F, Altayyar S, Ip WC Li G, Wang M, Wludarczyk A, Zhou Q, Guyatt GH, Cook DJ, Jaeschke R, 
Annane D; Fluids in Sepsis and Septic Shock Group. Fluid resuscitation in sepsis: a systematic review and network meta-analysis. Ann Intern Med. 2014;161(5):347-55. Review.

29. Niemi T, Miyashita R, Yamakage M. Colloid solutions: a clinical update. J Anesth. 2010;24(6):913-25. Review.

30. Basora M, Moral V, Llau JV, Silva S. [Perioperative colloid administration: a survey of Spanish anesthesiologists' attitudes]. Rev Esp Anestesiol Reanim. 2007;54(3):162-8. Spanish.

31. Hartog CS, Kohl M, Reinhart K. A systematic review of third-generation hydroxyethyl starch (HES 130/0.4) in resuscitation: safety not adequately addressed. Anesth Analg. 2011;112(3):635-45. Review.

32. Serpa Neto A, Veelo DP, Peireira VG, de Assunção MS, Manetta JA, Espósito DC, et al. Fluid resuscitation with hydroxyethyl starches in patients with sepsis is associated with an increased incidence of acute kidney injury and use of renal replacement therapy: a systematic review and meta-analysis of the literature. J Crit Care. 2014;29(1):185.e1-7. Review.

33. Westphal M, James MF, Kozek-Langenecker S, Stocker R, Guidet B, Van Aken H. Hydroxyethyl starches: different products--different effects. Anesthesiology. 2009;111(1):187-202. Review.

34. Treib J, Baron JF, Grauer MT, Strauss RG. An international view of hydroxyethyl starches. Intensive Care Med. 1999;25(3):258-68. Review.

35. Schortgen F, Lacherade JC, Bruneel F, Cattaneo I, Hemery F, Lemaire F, et al. Effects of hydroxyethylstarch and gelatin on renal function in severe sepsis: a multicentre randomised study. Lancet. 2001;357(9260):911-6.

36. Brunkhorst FM, Engel C, Bloos F, Meier-Hellmann A, Ragaller M, Weiler N, Moerer O, Gruendling M, Oppert M, Grond S, Olthoff D, Jaschinski U, John S, Rossaint R, Welte T, Schaefer M, Kern P, Kuhnt E, Kiehntopf M, Hartog C, Natanson C, Loeffler M, Reinhart K; German Competence Network Sepsis (SepNet). Intensive insulin therapy and pentastarch resuscitation in severe sepsis. N Engl J Med. 2008;358(2):125-39.

37. Myburgh JA, Finfer S, Bellomo R, Billot L, Cass A, Gattas D, Glass P, Lipman J, Liu B, McArthur C, McGuinness S, Rajbhandari D, Taylor CB, Webb SA; CHEST Investigators; Australian and New Zealand Intensive Care Society Clinical Trials Group. Hydroxyethyl starch or saline for fluid resuscitation in intensive care. N Engl J Med. 2012;367(20):1901-11.

38. Guidet B, Martinet 0 , Boulain T, Philippart F, Poussel JF, Maizel J, et al. Assessment of hemodynamic efficacy and safety of $6 \%$ hydroxyethylstarch
$130 / 0.4$ vs. $0.9 \% \mathrm{NaCl}$ fluid replacement in patients with severe sepsis: the CRYSTMAS study. Crit Care. 2012;16(3):R94.

39. Perner A, Haase N, Guttormsen AB, Tenhunen J, Klemenzson G, Åneman A Madsen KR, Møller MH, Elkjær JM, Poulsen LM, Bendtsen A, Winding R, Steensen M, Berezowicz P, Søe-Jensen P, Bestle M, Strand K, Wiis J, White JO Thornberg KJ, Quist L, Nielsen J, Andersen LH, Holst LB, Thormar K, Kjældgaard AL, Fabritius ML, Mondrup F, Pott FC, Møller TP, Winkel P, Wetterslev J; 6S Trial Group; Scandinavian Critical Care Trials Group. Hydroxyethyl starch 130/0.42 versus Ringer's acetate in severe sepsis. N Engl J Med. 2012;367(2):124-34. Erratum in: N Engl J Med. 2012;367(5):481.

40. Patel A, Waheed U, Brett SJ. Randomised trials of $6 \%$ tetrastarch (hydroxyethyl starch $130 / 0.4$ or 0.42 ) for severe sepsis reporting mortality: systematic review and meta-analysis. Intensive Care Med. 2013;39(5):811-22. Review.

41. Cochrane Injuries Group Albumin Reviewers. Human albumin administration in critically ill patients: systematic review of randomised controlled trials. BMJ. 1998;317(7153):235-40.

42. Finfer S, Bellomo R, Boyce N, French J, Myburgh J, Norton R; SAFE Study Investigators. A comparison of albumin and saline for fluid resuscitation in the intensive care unit. N Engl J Med. 2004;350(22):2247-56.

43. Vincent JL. Relevance of albumin in modern critical care medicine. Best Pract Res Clin Anaesthesiol. 2009;23(2):183-91. Review.

44. Vincent JL, Russell JA, Jacob M, Martin G, Guidet B, Wernerman J, et al Albumin administration in the acutely ill: what is new and where next? Crit Care. 2014;18(4):231. Erratum in: Crit Care. 2014;18(6):630. Roca, Ricard Ferrer [corrected to Ferrer, Ricard].

45. SAFE Study Investigators; Australian and New Zealand Intensive Care Society Clinical Trials Group; Australian Red Cross Blood Service; George Institute for International Health, Myburgh J, Cooper DJ, Finfer S, Bellomo R, Norton R, Bishop N, Kai Lo S, Vallance S. Saline or albumin for fluid resuscitation in patients with traumatic brain injury. N Engl J Med. 2007;357(9):874-84.

46. SAFE Study Investigators, Finfer S, McEvoy S, Bellomo R, McArthur C, Myburgh J, Norton R. Impact of albumin compared to saline on organ function and mortality of patients with severe sepsis. Intensive Care Med. 2011;37(1):86-96.

47. Caironi P, Tognoni G, Masson S, Fumagalli R, Pesenti A, Romero M, Fanizza C Caspani L, Faenza S, Grasselli G, lapichino G, Antonelli M, Parrini V, Fiore G, Latini R, Gattinoni L; ALBIOS Study Investigators. Albumin replacement in patients with severe sepsis or septic shock. N Engl J Med. 2014;370(15):1412-21. 